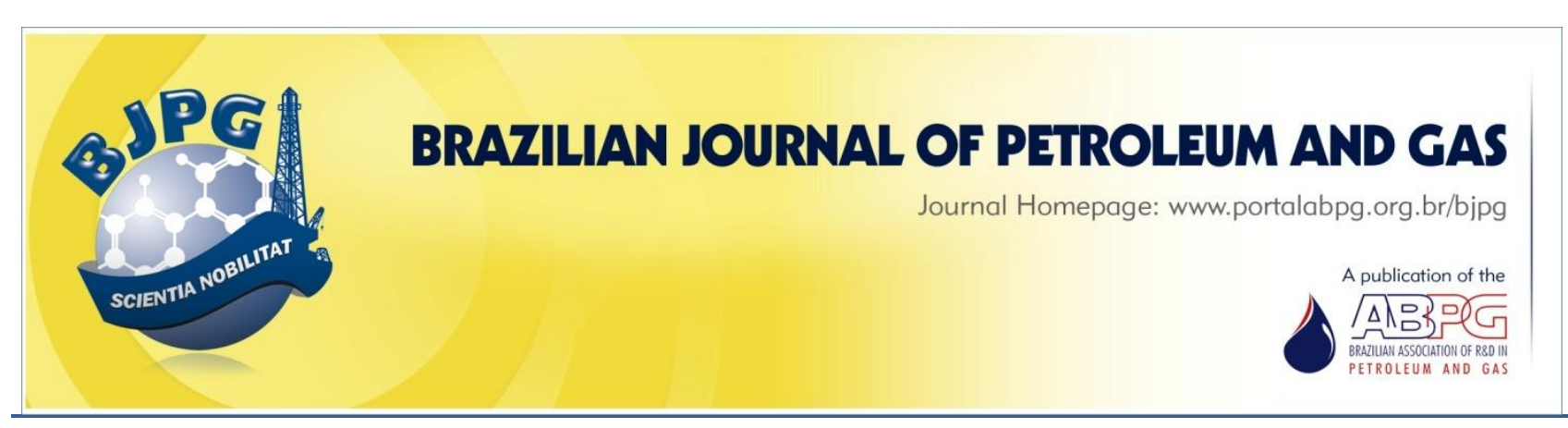

\title{
MECHANICAL AND PETROPHYSICAL ANALYSIS OF SYNTHETIC SANDSTONE FOR ENHANCED OIL RECOVERY APPLICATIONS
}

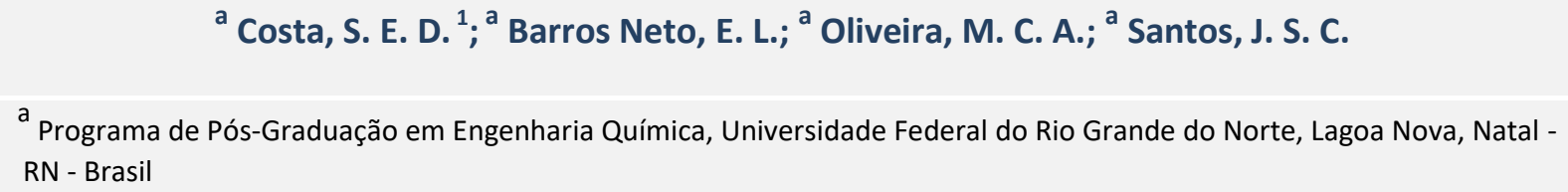

Received: 23.02.2017 / Revised: 02.08.2017 / Accepted: 16.08.2017 / Published on line: 16.10.2017

\begin{abstract}
The present work aims to develop a methodology for the preparation of synthetic sandstone to be used in enhanced oil recovery (EOR) studies. It also analyzes synthetic sandstone's properties. A $2^{3}$ factorial planning with central point in triplicate was performed, evaluating parameters such as concentration of ceramic clay, compaction pressure and sintering temperature through porosity, permeability, and uniaxial compression strength. The sandstone produced presented porosity and permeability similar to those found in natural rocks, which make them suitable for use in EOR research.
\end{abstract}

\section{KEYWORDS}

synthetic sandstone; porosity; permeability; uniaxial compression strength; enhanced oil recovery

\footnotetext{
${ }^{1}$ To whom all correspondence should be addressed.

Address: Programa de Pós-Graduação em Engenharia Química, Universidade Federal do Rio Grande do Norte, Lagoa Nova, Natal - RN - Brasil.

ZIP Code: 59078-970 | Phone: +55(84)99666-4882 |e-mail: semuelebenezer@hotmail.com doi:10.5419/bjpg2017-0011
} 


\section{INTRODUCTION}

Currently, Petroleum is the main source of energy on the planet (Tarifa et al., 2016). Due to the high demand for petroleum, many researchers try to find ways to increase its production. Recovery processes can be used to increase well production. Primary recovery depends only on reservoir pressure, while secondary recovery involves water and immiscible gas injection (Aguiar \& Mansur, 2016). Since, during extraction, two thirds of oil remains inside the reservoir, even after both the primary and secondary recoveries (Lu et al., 2014; Yuan et al., 2015), the use of enhanced oil recovery (EOR) method becomes necessary to maximize production.

EOR studies in oil laboratories have been performed with several types of reservoir rocks, such as limestone and Botucatu and Berea sandstones (Cardoso \& Balaban, 2015; Santos, 2015; Soares, 2012). However, samples from natural sources are difficult to obtain, and usually they are anisotropic (that is, they present different properties when analyzed from different directions), and may be expensive to acquire (Fattahpour et al., 2014; Marques et al., 2011). Therefore, the utilization of homogeneous analogous synthetic samples for experimental testing can be an advantage (Costa, 2016).

Ceramic clay is a naturally available material, presenting very fine grain size, which acquires some plasticity when moistened. It is made from crystal particles from a restricted number of minerals known as clay minerals, which are composed of hydrous aluminium and iron silicates, and contain a certain amount of alkaline and alkaline earth elements. Even though the clay may be molded easily, prior to sintering, after this process it presents a tough, firm shape (Avelino, 2013). When mixed with sand, it allows the making of consolidated porous media.

In this context, the present work aims to obtain homogeneous synthetic sandstone from mixing sand and ceramic clay to be used potentially in EOR studies, to analyze its mechanical (uniaxial compression strength) and petrophysical (porosity and permeability) properties and, then, compare those to natural anisotropic sandstone samples used in EOR.

\section{MATERIALS AND METHODS}

\subsection{Synthetic sandstone preparation}

The synthetic sandstone samples were prepared using sand from the Redinha beach (Natal/RN, Brazil) and ceramic clay (Lagoa de Velhos/RN, Brazil). The present work evaluated the amount of ceramic clay, compaction pressure, and sintering. The methodology was carried out as follows.

a) The impurities (roots) were removed from the ceramic clay. Following, the clay was set to dry

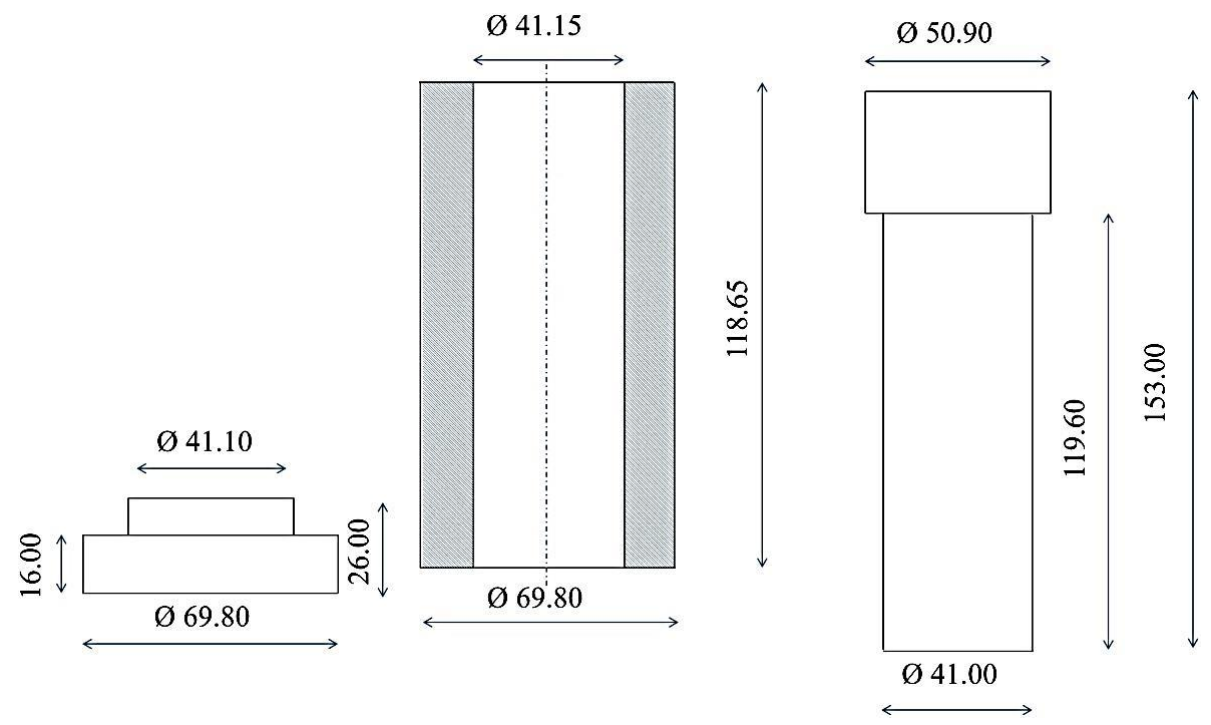

Figure 1. Cast used in sample compaction (mean scale in $\mathrm{mm}$ ). 
Table 1. Sandstone production experimental planning.

\begin{tabular}{cccc}
\hline Process variable & Upper level (+1) & Central level (0) & Lower level (-1) \\
\hline $\mathrm{C}^{\mathrm{a}}(\% \mathrm{~m} / \mathrm{m})$ & 40 & 30 & 20 \\
$\mathrm{P}^{\mathrm{b}}\left(\mathrm{kgf} / \mathrm{cm}^{2}\right)$ & 200 & 150 & 100 \\
$\mathrm{~T}^{\mathrm{c}}(\mathrm{o} \mathrm{C})$ & 950 & 900 & 850 \\
\hline
\end{tabular}

$\mathrm{C}^{\mathrm{a}}$ : Ceramic clay content; $\mathrm{P}^{\mathrm{b}}$ : Compaction pressure; $\mathrm{T}^{\mathrm{c}}$ : Sintering temperature.

for 24 hours at $110{ }^{\circ} \mathrm{C}$ in a lab oven. Then, the clay was ground in a ball mill for 1 hour, and sifted in a 200-mesh sieve. Contents used in the mixture were 20,30 , and $40 \%$ in weight;

b) The sand was sifted and the $(-65+100)$ mesh fraction (mean diameter of $181.0 \mu \mathrm{m}$ ) was used because it presented a diameter similar to the Berea sandstone $(170 \mu \mathrm{m})$ (Rutter \& Glover, 2012);

c) The ceramic clay and sand were mixed $(60$ grams total weight) and either 4.0 or $4.2 \mathrm{~mL}$ of water were added to the mixture $(4.0 \mathrm{~mL}$ in the 20 and $30 \%$ ceramic clay concentration, and $4.2 \mathrm{~mL}$ in the $40 \%$ one) to mix the components and hydrate the ceramic clay. The homogenization lasted 10 minutes and the mixture was inserted in the cast (Figure 1) for compaction, at 100,150 , and $200 \mathrm{kgf} / \mathrm{cm}^{2}$. After compaction, the samples were taken off the cast and dried for $24 \mathrm{~h}$ at $115^{\circ} \mathrm{C}$ in a lab oven;

d) Finally, the samples were sintered in a furnace at a $10^{\circ} \mathrm{C} / \mathrm{min}$ heating rate, at temperatures of 850,900 , and $950{ }^{\circ} \mathrm{C}$ for 3 hours.

A $2^{3}$ factorial planning with central point in triplicate (Table 1) was used to evaluate the effect of each factor over the variables in question. The tests used the software Statistica 8.0. The variables adopted for analysis were porosity, permeability, and uniaxial compression strength.

\subsection{Porosity (Ф)}

The sandstone measurements were obtained using a caliper rule, and the porosities were acquired using a porosimeter as shown in Figure 2. The sandstone samples were accommodated inside the porosimeter in chamber (b), and the porous volume was obtained from the relationship between initial pressure from chamber (a) and the system total pressure from chambers (a) $+($ b). Thus, based on the relationships described above, the porosity was determined (Costa, 2016).

\subsection{Permeability (k)}

The permeabilities of the synthetic sandstone samples were acquired through an experiment using the fluid injection system presented in Figure 3. The pump flow rate was kept at approximately 3 $\mathrm{mL} / \mathrm{min}$. The values of plug dimensions, viscosity, injected fluid flow rate, and system pressure were applied to Darcy's Law (Equation 1) to obtain the sample's permeability.

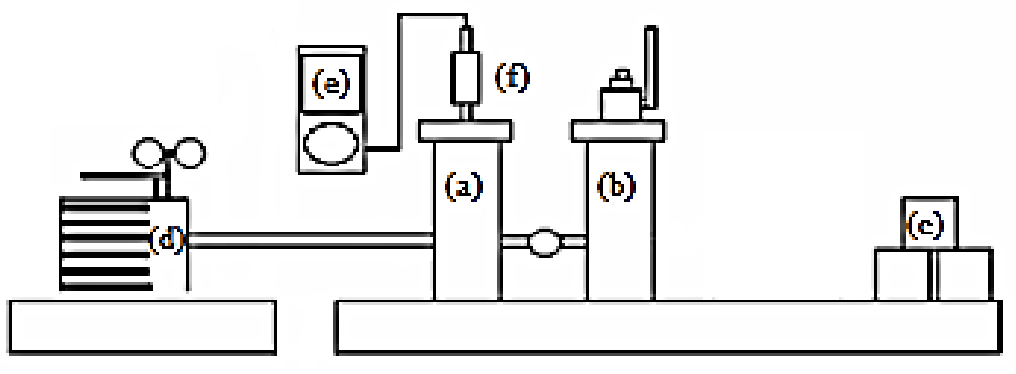

Figure 2. Porosimeter: (a) cell 1, (b) cell 2, (c) steel bodies used as standard volume, (d) compressor, (e) manometer, and (f) pressure transducer. 


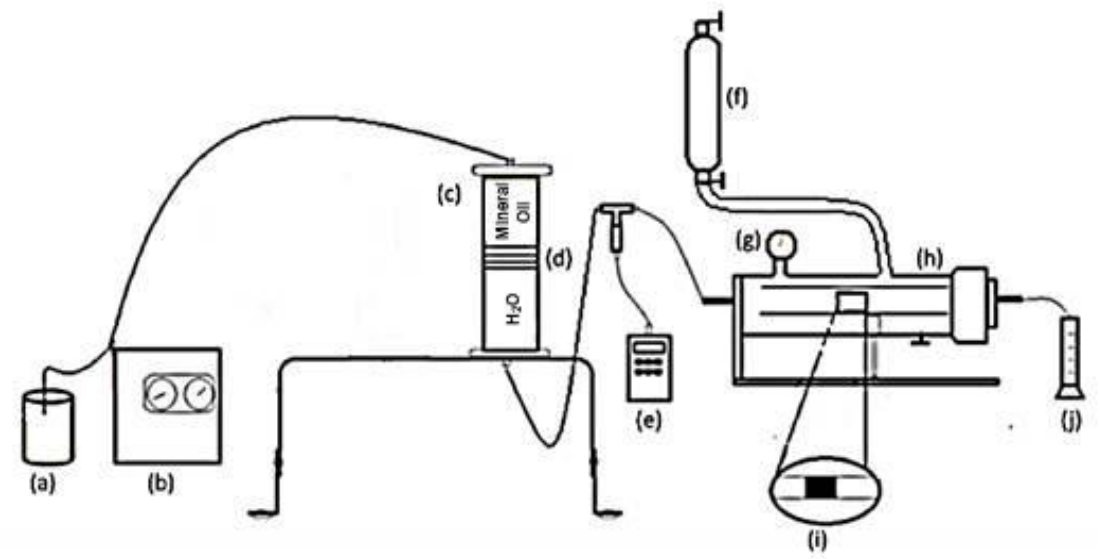

Figure 3. Permeability experiment system: (a) mineral oil flask, (b) injection pump, (c) acrylic cell, (d) piston, (e) internal pressure manometer, $(f)$ compressed air cylinder, $(g)$ external pressure manometer, (h) holder, (i) synthetic sandstone, and (j) cylinder.

$k=\frac{-q \mu L}{A \Delta P}$

Where:

$\mathrm{k}=$ absolute permeability of porous medium $(\mathrm{mD})$;

$q=$ fluid flow rate through porous medium $(\mathrm{cm} 3 / \mathrm{s})$;

$\mu=$ fluid viscosity (cP);

$\mathrm{L}=$ porous medium length $(\mathrm{cm})$;

$A=$ transversal area open to flow $(\mathrm{cm} 2)$;

$\Delta \mathrm{P}=$ head loss (atm).

\subsection{Uniaxial Compression Strength (UCS)}

The samples were sanded until they reached 1.5 $\mathrm{cm}$ height and their uniaxial compression strengths were analyzed using the AG-I $100-k N$ universal mechanical testing machine. The testing occurred at room temperature $\left(25^{\circ} \mathrm{C}\right)$.

\section{RESULTS AND DISCUSSION}

Figure 4 displays samples of sandstone sintered at different temperatures.

The synthetic sandstone plugs presented physical consistence. The experiment analyzes the samples' porosity, permeability, and uniaxial compression strength. The results are displayed in Table 2, where $C^{\mathrm{a}}$ is concentration of ceramic clay, $\mathrm{P}^{\mathrm{b}}$ is compaction pressure, $\mathrm{T}^{\mathrm{c}}$ is sintering temperature, $\Phi^{d}$ is porosity, $k^{e}$ is permeability and $\mathrm{UCS}^{f}$ is uniaxial compression strength.

The Pareto charts for porosity, permeability, and uniaxial compression strength were based on the results displayed in Table 2 (Figure 5). One can be observe that concentration of ceramic clay is the most relevant parameter, followed by the compaction pressure. One can also note that the increase in ceramic clay content causes a decrease in porosity and permeability. The physical reason for that resides at the binder distribution (clay) between the grains. For lower ceramic clay contents, the clay is found in the grains' contact area, creating binder bonds that, when sintered, get harder and unite sand particles. As the amount of clay increases, the number of bonds and their extensions increase. At a certain moment, this increase promotes the involvement of particles and the filling of empty spaces, leading to the reduction of porosity and permeability (Holt et al., 2005).

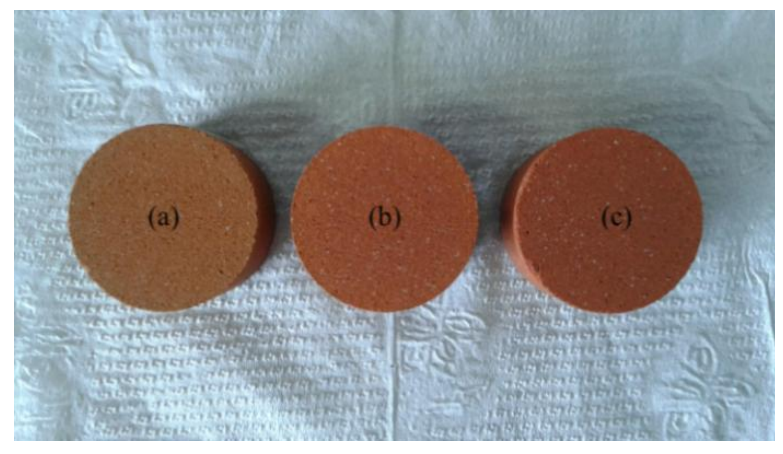

Figure 4. Sandstone samples sintered at (a) $850^{\circ} \mathrm{C}$, (b) $900^{\circ} \mathrm{C}$, and (c) $950^{\circ} \mathrm{C}$. 
Table 2. Results from the $2^{3}$ factorial planning with central point in triplicate.

\begin{tabular}{ccccccc}
\hline Number & $\mathbf{C}^{\mathrm{a}}$ & $\mathbf{P}^{\mathrm{b}}$ & $\mathbf{T}^{\mathrm{c}}$ & $\boldsymbol{\Phi}^{\mathrm{d}}(\%)$ & $\mathbf{k}^{\mathrm{e}}(\mathbf{m D})$ & $\mathbf{U C S}^{\mathrm{f}}(\mathbf{M P a})$ \\
\hline 1 & - & - & - & 61.2996 & 21.9548 & 2.3391 \\
2 & + & - & - & 54.8204 & 3.8952 & 26.4793 \\
3 & - & + & - & 59.6067 & 13.1160 & 4.5558 \\
4 & + & + & - & 50.9985 & 2.6718 & 39.2123 \\
5 & - & - & + & 61.9282 & 25.1389 & 1.5780 \\
6 & + & - & + & 54.6267 & 5.5531 & 22.2442 \\
7 & - & + & + & 59.6216 & 14.0688 & 2.7423 \\
8 & + & + & + & 51.2338 & 3.8726 & 31.7800 \\
9 & 0 & 0 & 0 & 56.7968 & 9.6678 & 12.0961 \\
10 & 0 & 0 & 0 & 56.7026 & 8.9974 & 15.2574 \\
11 & 0 & 0 & 0 & 56.7968 & 9.7939 & 11.2369 \\
\hline
\end{tabular}

The increase in pressure during sample preparation also leads to a decrease in porosity and permeability. This phenomenon happens due to the greater compaction of particles at higher pressures (Costa, 2016).

Increases in temperature increase permeability and, in general, also affect porosity. This is due to the greater volumetric dilatation of the beach sand, rich in silicon, at higher temperatures. The silicon sand expands when exposed to temperatures around $500{ }^{\circ} \mathrm{C}$ (Soares, 2000), and that dilatation leads to the formation of additional empty and permeable spaces inside the synthetic sandstone.

Since the UCS presents an opposite behavior from the porosity (Fattahpour et al., 2014), an increase in evaluated variables is observed as the
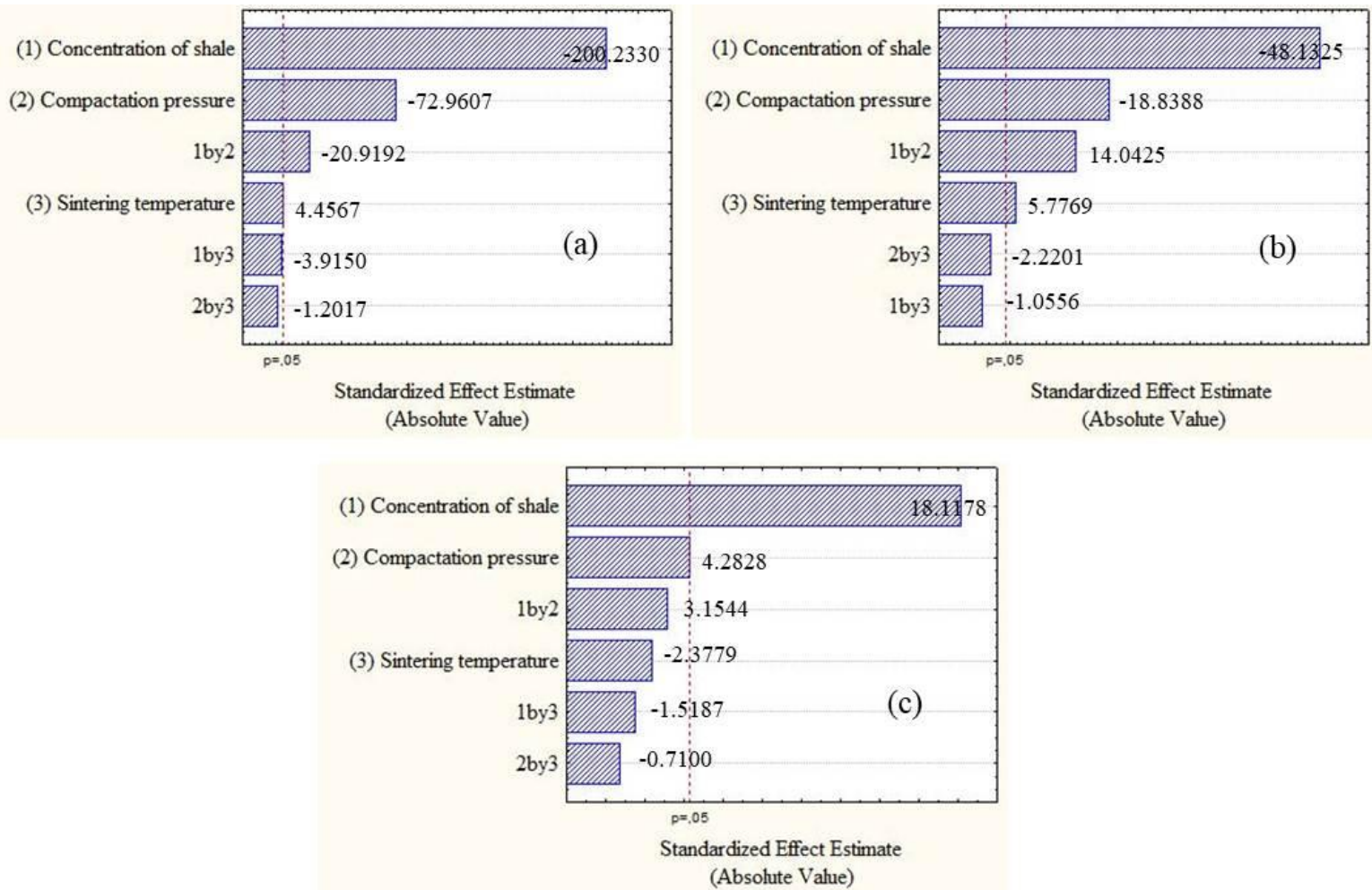

Figure 5. Pareto Diagrams for (a) porosity, (b) permeability, (c) uniaxial compression strength, with a $95 \%$ confidence level. 

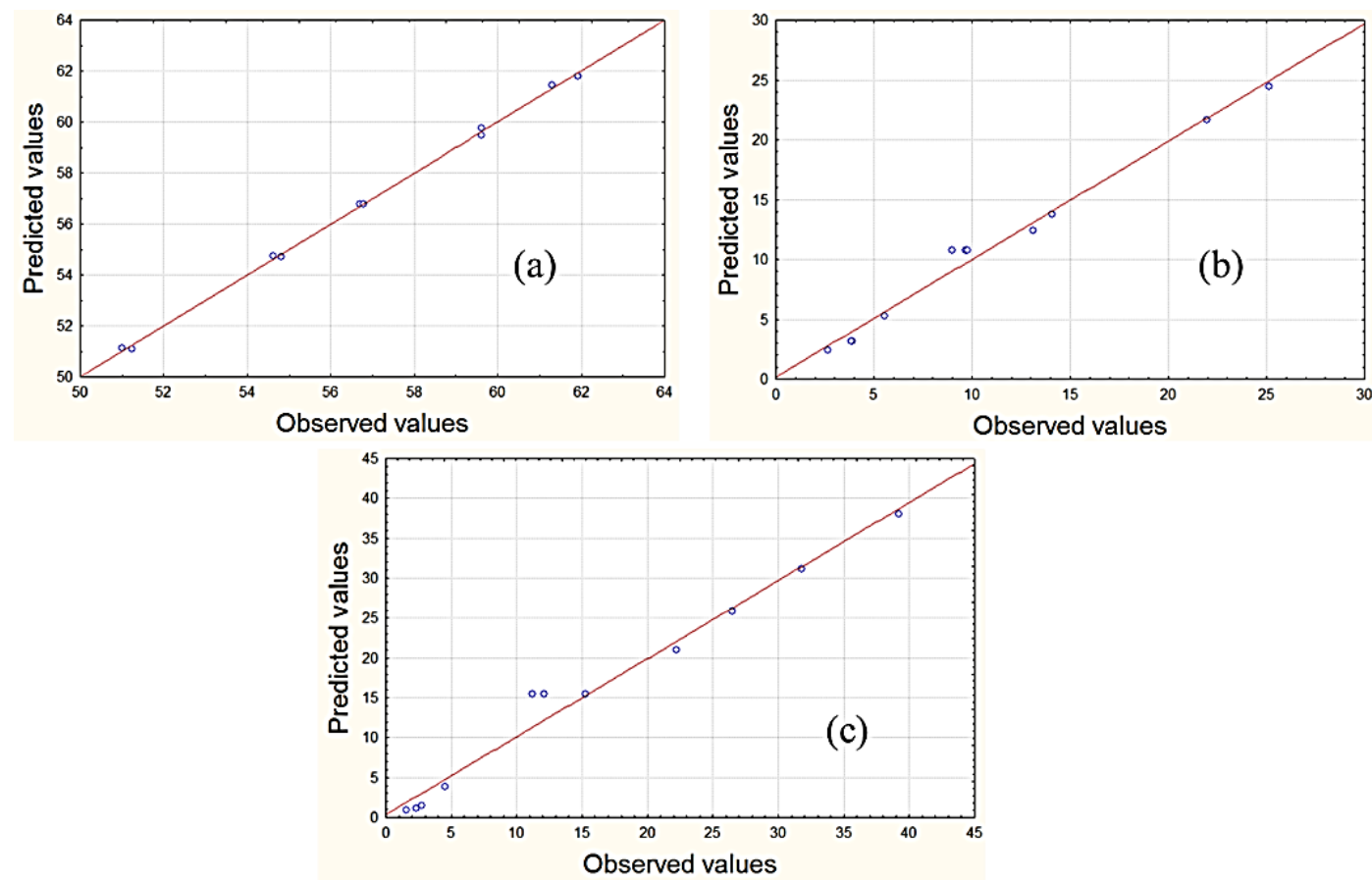

Figure 6. Real and predicted values for (a) porosity, (b) permeability, and (c) uniaxial compression strength.

ceramic clay content and compaction pressure increase and sintering temperature decreases.

Through coefficient regression, linear models for porosity (Equation 2), permeability (Equation 3 ), and uniaxial compression strength (Equation 4) were obtained. The significant effects from each equation appear below in bold.

$\Phi=56.767-3.847 \mathrm{C}-1.402 \mathrm{P}+0.086 \mathrm{~T}-$

$-0.402 \mathrm{CP}-0.075 \mathrm{CT}-0.023 \mathrm{PT}$

$\mathrm{k}=10.794-7.286 \mathrm{C}-2.852 \mathrm{P}+\mathbf{0 . 8 7 4} \mathrm{T}+$

$+2.126 \mathrm{CP}-0.160 \mathrm{CT}-0.336 \mathrm{PT}$

UCS $=15.411+13.562 \mathrm{C}+3.206-1.780 \mathrm{~T}+$

$+2.361 \mathrm{CP}-1.137 \mathrm{CT}-0.531 \mathrm{PT}$
Figure 6 presents the experimental data and the linear models for each variable.

The proximity between real data and linear fitting reveals that Equations 2, 3, and 4 are capable of modeling the experimental data properly.

To validate the empirical models, analysis of variance (ANOVA) and F-tests were conducted. The results can be seen in Tables 3, 4, and 5 .

The values of the quadratic sums and degrees of freedom were obtained using the Statistica 8.0 software, and the quadratic means were acquired by dividing the former and the latter. The $F_{1}$ parameters were obtained through the ratio between the regression and residue quadratic

Table 3. ANOVA for porosity $\left(R^{2}=0.9986\right)$.

\begin{tabular}{cccccc}
\hline Source of variation & Quadratic sum & $\begin{array}{c}\text { Degrees of } \\
\text { freedom }\end{array}$ & Mean square & $\mathbf{F}_{\text {calculated }}$ & $\mathbf{F}_{\text {table }}$ \\
\hline Regression & 135.4726 & 4 & 33.8682 & $F_{1}=1061.6975$ & $F_{1}=4.53$ \\
Residual & 0.1914 & 6 & 0.0319 & & \\
Lack of Fit & 0.1855 & 4 & 0.0464 & $F_{2}=15.7203$ & $F_{2}=19.25$ \\
Pure Error & 0.0059 & 2 & 0.0030 & & \\
Total & 135.6640 & 10 & & & \\
\hline
\end{tabular}


Table 4. ANOVA for permeability $\left(R^{2}=0.9835\right)$.

\begin{tabular}{cccccc}
\hline Source of variation & Quadratic sum & $\begin{array}{c}\text { Degrees of } \\
\text { freedom }\end{array}$ & Mean square & $\mathbf{F}_{\text {calculated }}$ & $\mathbf{F}_{\text {table }}$ \\
\hline Regression & 531.9697 & 4 & 132.9920 & $F_{1}=89.4849$ & $F_{1}=4.53$ \\
Residual & 8.9172 & 6 & 1.4862 & & \\
Lack of Fit & 8.5506 & 4 & 2.1377 & $F_{2}=11.6620$ & $F_{2}=19.25$ \\
Pure Error & 0.3666 & 2 & 0.1833 & & \\
Total & 540.8869 & 10 & & & \\
\hline
\end{tabular}

Table 5. ANOVA for UCS $\left(R^{2}=0.8798\right)$.

\begin{tabular}{cccccc}
\hline Source of variation & Quadratic sum & $\begin{array}{c}\text { Degrees of } \\
\text { freedom }\end{array}$ & Mean square & $\mathbf{F}_{\text {calculated }}$ & $\mathbf{F}_{\text {table }}$ \\
\hline Regression & 1471.4950 & 1 & 1471.4950 & $\mathrm{~F}_{1}=65.8584$ & $\mathrm{~F}_{1}=5.12$ \\
Residual & 201.0900 & 9 & 22.3433 & & \\
Lack of Fit & 192.1250 & 7 & 27.4464 & $\mathrm{~F}_{2}=6.1230$ & $\mathrm{~F}_{2}=19.35$ \\
Pure Error & 8.9650 & 2 & 4.4825 & & \\
Total & 1672.5850 & 10 & & & \\
\hline
\end{tabular}

Table 6. Porosities and permeabilities of natural rocks.

\begin{tabular}{cccc}
\hline Rock & Reference & $\mathbf{\Phi} / \%$ & $\mathbf{k} / \mathbf{~ m D}$ \\
\hline Açu Sandstone & Curbelo (2006) & 24.00 to 29.78 & 1.21 to 8.36 \\
Limestone & Soares (2012) & 48.99 to 74.28 & - \\
Botucatu Sandstone & Souza (2013) & 28.81 to 44.05 & - \\
Berea Sandstone & Rosenbrand et al. (2014) & 18 & 9.8 to 13.7 \\
Botucatu Sandstone & Firmino (2016) & 37.19 to 54.96 & - \\
Botucatu Sandstone & This work & 44.51 to 57.84 & 24.76 to 28.09 \\
Berea Sandstone & This work & 20.41 & 2.43 \\
Synthetic Sandstone & This work & 50.998 to 61.928 & 2.672 to 25.139 \\
\hline
\end{tabular}

means; the $F_{2}$ parameters, through the ratio between lack of adjustment and pure error quadratic means. This was done to make the comparison of tabulated values possible.

According to the results presented in Tables 3, 4, and 5; one can state that the models are significant, since the calculated $F_{1}$ was higher than the reference $F_{1}$, and predictive, since the calculated $F_{2}$ was smaller than the reference $F_{2}$. Thus, the models may be used to predict results inside the chosen factors domain (Barros Neto et al., 2001). The determination coefficient $\left(R^{2}\right)$ was applied to assess the adjustment of the models to the experimental data. The correlation between values calculated using the models and the experimental ones improves as $R^{2}$ reaches 1 . This indicates that the models well represent the results obtained experimentally (Carvalho et al. 2016). Thus, the best determination coefficient was achieved with the porosity analysis, followed by the permeability. The determination coefficient found for uniaxial compression strength was the lowest one, probably due to the error displayed in Figure 6c, where two points presenting values between 11 and 13 distance themselves from the main diagonal; while most data points are exactly on the diagonal or very close to it, indicating that the results from this parameter are also reproducible.

The response surfaces are displayed in Figure 7. They show the linear behavior between the evaluated variables and the concentration of ceramic clay and compaction pressure. It is also noticeable that lower values of these two properties lead to higher values of porosity and permeability, and to lower uniaxial compression strength values. 


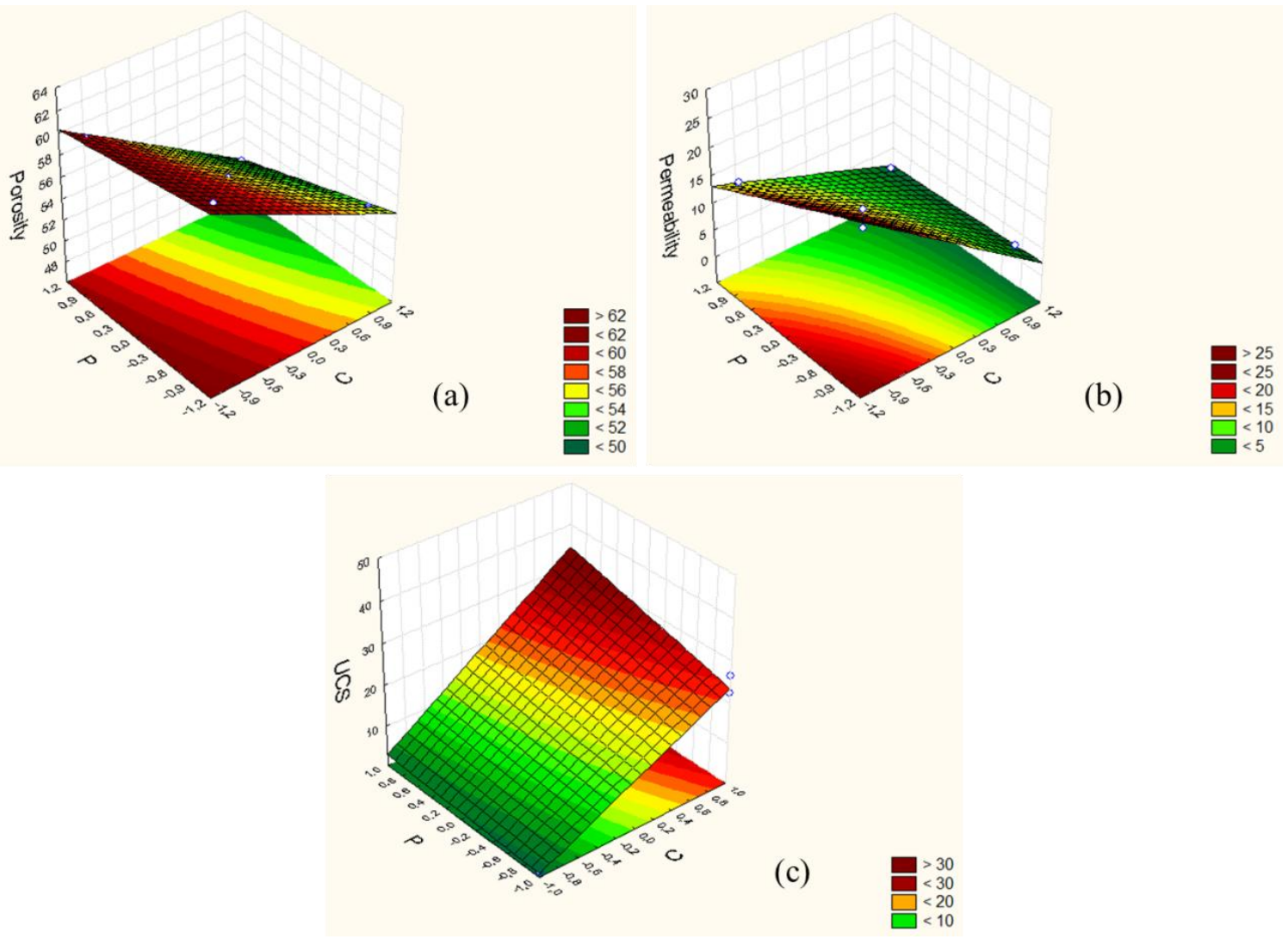

Figure 7. Response surfaces at $\mathrm{T}=900{ }^{\circ} \mathrm{C}$ for (a) porosity, (b) permeability, and (c) uniaxial compression strength.

Since the petrophysical properties porosity and permeability are important to reservoir rocks, the values found for the synthetic sandstone can be compared to the natural rocks' ones, most commonly used in studies involving enhanced oil recovery, as shown in Table 6.

One can observe that porosity and permeability ranges for the synthetic sandstone are similar to the ones found in natural rocks used in EOR studies, which supports the utilization of synthetic sandstone samples in these studies.

\section{CONCLUSION}

The goal of the present work was to develop a methodology to prepare homogeneous synthetic sandstone plugs by mixing sand and clay to be used in enhanced oil recovery research projects. It also sought to evaluate synthetic sand plugs' properties and compare those to anisotropic natural sandstone samples used in EOR. Based on the results achieve, one can obtain the following conclusions:
- It is possible to obtain synthetic sandstone by mixing and sintering beach sand and ceramic clay;

- Increases in compaction pressure and ceramic clay content along with decreases in temperature lead to lower porosities and permeability, and higher uniaxial compression strength of synthetic sandstones;

- Based on statistical analysis, the concentration of ceramic clay was the most relevant parameter;

- The acquired models were adequate to describe the data;

- Linear behaviors were obtained between evaluated variables, ceramic clay content, and compaction pressure;

- Finally, porosity and permeability ranges found for the synthetic sandstone samples are similar to the ones from natural rocks, supporting the utilization of those samples in enhanced oil recovery research projects. 


\section{ACKNOWLEDGEMENTS}

The authors acknowledge the financial support in the form of scholarships and research grants by ANP, Petrobras, and CAPES. They also recognize the physical and scientific support given by UFRN.

\section{REFERENCES}

Aguiar, J. I. S.; Mansur, C. R. E. The influence of polymer flooding on produced oily water: a review. Brazilian Journal of Petroleum and Gas, v. 10 (1), p. 049-061, 2016.

https://doi.org/10.5419/bipg2016-0005

Avelino, K. A. R. Estudo da potencialidade da incorporação de resíduos de granito e da queima da casca do café em cerâmicas vermelhas. $81 \mathrm{f}$. Dissertação de Mestrado. Programa de PósGraduação em Ciência e Engenharia dos Materiais, Universidade Federal do Rio Grande do Norte, 2013. (in Portuguese).

Barros Neto, B.; Scarminio, I. S.; Bruns, R. E. Como fazer experimentos: pesquisa $e$ desenvolvimento na ciência e na indústria. Campinas, SP: Editora UNICAMP, 2001. 401f. (in Portuguese)

Cardoso, O. R.; Balaban, R. D. C. Comparative study between Botucatu and Berea sandstone properties. Journal of South American Earth Sciences, v. 62, p. 58-69, 2015.

https://doi.org/10.1016/j.jsames.2015.04.004

Carvalho, P. C. A. P.; Foletto, E. L.; Barros Neto, E. L.; Chiavone-Filho, O. Oil removal from oilfield produced water by sand filter. Brazilian Journal of Petroleum and Gas, v. 10 (3), p. 161-170, 2016. https://doi.org/10.5419/bipg2016-0013

Costa, S. E. D. Preparo de arenitos sintéticos e estudo de suas propriedades para uso na recuperação avançada de petróleo. 87f. Dissertação de Mestrado. Programa de PósGraduação em Engenharia Química, Universidade Federal do Rio Grande do Norte, 2016. (in Portuguese).

Curbelo, F. D. S. Recuperação avançada de petróleo utilizando tensoativos. 217f. Tese de Doutorado. Programa de Pós-Graduação em Engenharia Química, Universidade Federal do Rio Grande do Norte, 2006. (in Portuguese).
Fattahpour, V.; Baudet, B. A.; Moosavi, M.; Mehranpour, M.; Ashkezari, A. Effect of grain characteristics and cement content on the unconfined compressive strength of artificial sandstones. International Journal of Rock Mechanics \& Mining Sciences, v. 72, p. 109-116, 2014. https://doi.org/10.1016/j.ijrmms.2014.09.008

Firmino, P. C. O. S. Influência de sistemas microemulsionados na molhabilidade de arenito e na recuperação de petróleo. 93f. Dissertação de Mestrado. Programa de Pós-Graduação em Engenharia Química, Universidade Federal do Rio Grande do Norte, 2016. (in Portuguese).

Holt, R.M.; Kjølaas, J.; Larsen, I.; Li, L.; Gotusso Pillitteri, A. ; Sønsteb $\varnothing$, E. F. Comparison between controlled laboratory experiments and discrete particle simulations of the mechanical behaviour of rock. International Journal of Rock Mechanics \& Mining Sciences, v. 42, p. 985-995, 2005. https://doi.org/10.1016/j.ijrmms.2005.05.006

Lu, J.; Liyanage, P. J.; Solairaj, S.; Adkins, S.; Arachchilage, G. P.; Kim, D. H.; Britton, C.; Weerasooriya, U.; Pope, G. A. New surfactant developments for chemical enhanced oil recovery. Journal of Petroleum Science and Engineering, v. 120, p. $94-101,2014$.

https://doi.org/10.1016/i.petrol.2014.05.021

Marques, L. C.; Appoloni, C. R.; Fernandes, C. P. Porosity study of synthetic sandstones by nondestructive nuclear techniques. Materials Research, v. 14 (3), p. 394-402, 2011. https://doi.org/10.1590/S1516-14392011005000048

Rosenbrand, E.; Haugwitz, C.; Jacobsen, P.S.M.; Kjøller, C.; Fabricius, I.L. The effect of hot water injection on sandstone permeability. Geothermics, v. 50, p. 155-166, 2014.

https://doi.org/10.1016/j.geothermics.2013.09.006

Rutter, E. H.; Glover, C. T. The deformation of porous sandstones; Are Byerlee friction and the critical state line equivalent? Journal of Structural Geology, v. 44, p. $129-140,2012$. https://doi.org/10.1016/i.jsg.2012.08.014

Santos, J. S. C. Avaliação de sistemas constituídos por polímeros/ tensoativo/ EDTA na recuperação avançada de petróleo. 99f. Tese de Doutorado. Programa de Pós-Graduação em Engenharia Química, Universidade Federal do Rio Grande do Norte, 2015. (in Portuguese). 
Soares, A. P. J. Aplicação de microemulsão na recuperação de petróleo de reservatórios carbonáticos. 177f. Dissertação de Mestrado. Programa de Pós-Graduação em Engenharia Química, Universidade Federal do Rio Grande do Norte, 2012. (in Portuguese).

Soares, G. A. Fundição: Mercado, Processos e Metalurgia. Rio de Janeiro, RJ: COPPE/UFRJ, 2000. 116p. (in Portuguese).

Souza, T. T. C. Nanoemulsões aplicadas à recuperação avançada de petróleo. $98 \mathrm{f}$. Dissertação de Mestrado. Programa de PósGraduação em Engenharia Química, Universidade Federal do Rio Grande do Norte, 2013. (in Portuguese).
Tarifa, J. M. ; Ruiz, C. P. A.; Barillas, J. L. M. Analyzing chemical reaction models for in situ combustion process. Brazilian Journal of Petroleum and Gas, v. 10, n.2, p. 089-103, 2016. https://doi.org/10.5419/bjpg2016-0008

Yuan, F. Q.; Cheng, Y. Q. ; Wang, H. Y. ; Xu, Z. C.; Zhang, L.; Zhang, L.; Zhao, S. Effect of organic alkali on interfacial tensions of surfactant solutions against crude oils. Colloids and Surfaces A: Physicochem. Eng. Aspects, v. 470, p.171-178, 2015. https://doi.org/10.1016/i.colsurfa.2015.01.059 